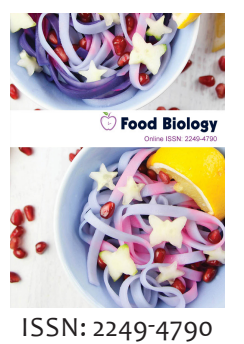

Received: June 17, 2020 Accepted: August 03, 2020 Published: August 10, 2020

*Corresponding Author:

Yasser A. El-Amier

Email:yasran@mans.edu.eg

\section{Proximate composition, mineral content and secondary metabolites of three medicinal wild Fagonia species}

\author{
Mustafa M. El-Zayat', Yasser A. El-Amier ${ }^{2 *}$, El-Sayed F. El-Halawany ${ }^{2}$ and \\ Iman A. Abo Aisha',3
}

'Unit of Genetic Engineering and Biotechnology, Mansoura University, ${ }^{2}$ Botany Department, Faculty of Science, Mansoura University, Mansoura, Egypt, ${ }^{3}$ Botany Department, Faculty of Education, Sabha University, Tragan, Libya

\begin{abstract}
Proximate composition of the aerial parts of three Fagonia species (Fagonia arabica L., F. mollis Delile and F. cretica L.) collected from different habitats were analyzed. Macro- and micro-elements as well as some secondary metabolites were estimated. The obtained results revealed that $F$. creticus contains appreciable levels of nutritive components considering that its nutritional value $(351.06 \mathrm{kcal} / 100 \mathrm{~g}$ dry wt.) was remarkably higher than that of F. arabica and F. mollis (327.99 and $293.07 \mathrm{kcal} / 100 \mathrm{~g}$ dry wt., respectively). The concentration of Na was relatively the highest among the other estimated macroelements in the studied species followed by $\mathrm{K}, \mathrm{Ca}$ and $\mathrm{Mg}$, respectively while Fe was the highest microelement followed by $\mathrm{Cu}, \mathrm{Mn}$ and $\mathrm{Zn}$, respectively. The phytochemical composition revealed that methanolic extract of F. creticus was the richest in total alkaloids and flavonoids, while F. arabica found to be the richest in total phenolics and tannins.
\end{abstract}

KEYWORDS: Fagonia, zygophyllaceae, phytochemical, minerals, bioactive compounds

\section{INTRODUCTION}

Plants are valuable sources of a wide range of secondary metabolites, which are used as pharmaceuticals, agrochemicals, flavors, and additives. Medicinal plants are the nature's gift to human to help them pursue a disease-free health life. Plants have been used as drugs by humans since thousands of years ago. As a result the accumulated experience from the past generations, today, all the world have an extensive knowledge of herbal medicine. Two thirds of the newly identified chemicals yearly were extracted from higher plants and $75 \%$ of the world population used plants for therapy and prevention $[1,2]$. The Medicinal values of plants are dictated by their phytochemical constituents [3]. Plants extracts contain many chemical compounds that are biologically active within the human body [4]. Plant derived substances have recently become of great interest owing to their versatile applications [5].

Many substances that we use in our daily life are plant products that could be used as drugs, flavorings, rubber, paint base, nonpetroleum oils, gums and sizing starches are also derived from plants, most important of all, is the edible plant product, that are the food base of human culture [6].

The genus Fagonia (Zygophyllaceae) is represented in Egypt by 18 species according to Tackholm [7], while Boulos [8] illustrated that this genus is represented by only 15 species. The species of this genus are characterized by palmate compound leaves, stiff stipules and purple flowers. It is found on dry calcareous rocks, sandy plains and desert wadis. It is widely distributed worldwide in North Africa, Spain, Balearic Islands, Sicily, Malta, Greece, Pakistan. In Egypt it occurs in the Mediterranean coastal strip, the oases of the western desert, all the deserts of Egypt and the entire Sinai Peninsula [8]. Species of genus Fagonia were extensively studied by many researchers regarding their medicinal uses, since these plants are known to be antitumor, antioxidant, analgesic, astringent, febrifuge and prophylactic against small-pox agents. Species of Fagonia were also used for the treatment of cancer in the indigenous system, fever, asthma, urinary discharges, toothache, stomach troubles and kidney diseases $[9,10]$. This genus is a rich source of triterpenes and saponins. Pharmacological studies of their aqueous extracts on animal have shown anticancer and some other important activities [11]. Methanolic extract of Fagonia cretica possessed anti-diabetic activity and have potential to reduce kidney damage, which would be helpful to reduce the kidney damage in patients suffering from long-term diabetes. It is suggested that active constituents of Fagonia cretica such as quinovic acid should be separated and evaluated for its efficacy in certain based therapies [12]. 
Scientific studies indicated that medicinal plants contain promising phytochemical compounds that could be developed for treatment of many health problems. Most plants carry a large number of unidentified compounds which can be really useful for making new drugs. Therefore, today efforts have been directed towards the discovery, isolation and development of natural products from various medicinal plants and animal sources [13-16]. The objectives of this research were to determine the proximate composition, mineral content and secondary metabolites of three wild medicinal species of genus Fagonia naturally growing in the different habitats of study area to evaluate their economic potentialities and to use them in various purposes as a raw natural resource.

\section{MATERIALS AND METHODS}

\section{Preparation of Plant Material}

The investigated Fagonia spp (Family, Zygophyllaceae) in the present study were collected from different habitats of the study area, these species are growing naturally in the Western Mediterranean coastal belt, Cairo-Suez Desert Road as well as Wadi Hagul region. The selected species of genus Fagonia include: Fagonia arabica L., Fagonia cretica L. and Fagonia mollis Delile. The identification of species was done according to Boulos [8]. The studied species were dried at room temperature and ground into a powder using a blender.

In the flowering stage, plant sample of the studied species were handly cleaned, washed several times with distilled water, dried at 55 to $60{ }^{\circ} \mathrm{C}$ (maximum) in a forced air oven for a maximum of 24 hours to reduce moisture content prior to grinding, then preserved in well stoppered bottles.

\section{Phytochemical Analysis}

The moisture content, dry matter, crude fiber, lipid content, ash and crude protein of Fagonia species were analyzed according to AOAC [17]. The total nitrogen was determined by the Kjeldahl method [18]. Glucose was determined based on the method of Feteris [19]. Sucrose was determined according to Handel [20]. Polysaccharides were estimated by the method of Thyumanavan and Sadasivam [21].

The method of extraction of different elements in the present study was described by Allen et al. [22]. Sodium and potassium were determined in sample by Flame Photometer (Model PHF 80 B Biologie Spectrophotometer), while calcium, magnesium, copper, zinc, iron and manganese were estimated using atomic absorption spectrometer (Perkin-Elmer, Model 2380. USA). These elements were expressed as $\mathrm{mg} \mathrm{g}^{-1}$ dry weight.

The content of total phenolic and tannins were determined spectrophotometrically according to methods of Sadasivam and Manickam [23] and Van Buren \& Robinson [24], respectively. Saponins content was estimated according to Obadoni and Ochuko[ 25], while the content of flavonoids was determined according to Boham and Kocipai-Abyazan [26]. The alkaloids were extracted with $10 \%$ acetic acid in ethanol and determined according to the method of Harborne [27].

\section{RESULTS AND DISCUSSION}

\section{Proximate Composition}

The proximate chemical composition of shoot system of each the studied Fagonia species is presented in Table 1. The moisture content of the investigated Fagonia species exhibited a narrow range of variation. It varied from $9.26 \%$ in F. mollis to $13.77 \%$ in F. criticus. The mean value of moisture content of F. arabica was $10.41 \%$. The highest percentage of dry matter was recorded in F. mollis (90.74\%), followed by F. arabica (89.59\%), then the lowest value was recorded in F. criticus $(86.23 \%)$. The usability and quality of food or forage such as the texture, taste, appearance and stability of foods depends on the amount of water they contain. Therefore, moisture content plays a key role in ensuring quality in many industries including food, pharmaceuticals and chemicals [28].

Dietary fiber is naturally present in vegetables, fruits, cereals and forage. The amount and composition of fibers differ from plant to plant [29]. Dietary fiber includes polysaccharide, lignin and associated plant materials. A fiber-rich diet is lower in energy density, often has a lower fat content, is larger in volume and is richer in micronutrients [30]. The results in (Table 1) showed considerable variations in the crude protein, fat, fiber, ash and carbohydrate contents among the three studied Fagonia species. The highest crude fiber and ash content was recorded in F. mollis (18.69 and $11.68 \%$, respectively) while the lowest was in F. creticus ( 9.23 and $7.58 \%$, respectively). On the contrary, the percentage of lipid varied between $2.91 \%$ in F. mollis and $4.63 \%$ in F. arabica. Lipids play an important role in living organisms as sources of energy, as structural components of membranes and/or as storage products of cells. The nutritional value of food and the human's health are affected by the variety and quantity of the lipids [31].

Table 1:Proximate constituent in the selected Fagonia species

\begin{tabular}{|c|c|c|c|}
\hline Nutrients & Fagonia arabica & F. creticus & F. mollis \\
\hline Moisture content \% & $10.41 \pm 0.87$ & $13.77 \pm 1.15$ & $9.26 \pm 0.77$ \\
\hline Dry matter \% & $89.59 \pm 5.47$ & $86.23 \pm 6.19$ & $90.74 \pm 7.56$ \\
\hline Total ash \% & $9.22 \pm 0.77$ & $7.58 \pm 0.63$ & $11.68 \pm 0.97$ \\
\hline Crude fiber \% & $14.57 \pm 1.21$ & $9.23 \pm 0.77$ & $18.69 \pm 1.56$ \\
\hline Crude lipid \% & $4.63 \pm 0.39$ & $3.66 \pm 0.31$ & $2.91 \pm 0.24$ \\
\hline Crude protein \% & $9.34 \pm 0.78$ & $11.67 \pm 0.97$ & $6.19 \pm 0.52$ \\
\hline Total nitrogen \% & $1.49 \pm 0.12$ & $1.87 \pm 0.16$ & $0.99 \pm 0.08$ \\
\hline \multicolumn{4}{|c|}{ Carbohydrates (mg g-1 dry weight) } \\
\hline Glucose & $1.13 \pm 0.09$ & $1.85 \pm 0.15$ & $0.89 \pm 0.07$ \\
\hline Sucrose & $9.67 \pm 0.81$ & $12.54 \pm 1.05$ & $7.44 \pm 0.62$ \\
\hline Total soluble sugar & $29.68 \pm 2.47$ & $38.55 \pm 2.21$ & $12.43 \pm 1.04$ \\
\hline Polysaccharides & $133.47 \pm 7.12$ & $167.49 \pm 9.64$ & $88.67 \pm 5.39$ \\
\hline \multicolumn{4}{|l|}{ Calculated parameters } \\
\hline $\begin{array}{l}\text { Total Carbohydrates } \\
\text { (mg g } \mathrm{m}^{-1} \text { dry weight) }\end{array}$ & $622.4 \pm 11.64$ & $678.6 \pm 13.41$ & $605.3 \pm 8.57$ \\
\hline $\begin{array}{l}\text { Nutritive Value (Cal } \\
\left(00 \mathrm{~g}^{-1}\right)\end{array}$ & $327.99 \pm 11.04$ & $351.06 \pm 9.82$ & $293.07 \pm 6.87$ \\
\hline $\begin{array}{l}\text { Total digestible } \\
\text { nutrients \% }\end{array}$ & $59.18 \pm 2.37$ & $56.75 \pm 2.11$ & $60.11 \pm 1.89$ \\
\hline
\end{tabular}


The results in (Table 1) showed obvious variation in total nitrogen content in the studied Fagonia species. The highest percentage was recorded in F. creticus (1.87\%), while the lowest value was estimated in F. mollis (0.99\%). The protein content varied from $6.19 \%$ in F. mollis to $11.67 \%$ in F. creticus. The majority of living tissues and organs need proteins and other elements as their building blocks. Therefore, on a global basis, plant protein foods contribute over $60 \%$ of the per capita supply of protein, on average [32].

The obtained results indicated that, the values of glucose ranged from $0.89 \mathrm{mg} / \mathrm{g}$ dry weight in F. mollis to $1.85 \mathrm{mg} / \mathrm{g}$ dry weight in F. creticus. On the other hand, the highest contents of sucrose were recorded in F. creticus (12.54 mg/g dry weight), while the lowest values were estimated in F. mollis ( $7.44 \mathrm{mg} / \mathrm{g}$ dry weight). The highest values of the total soluble sugars were recorded in F. creticus $(38.55 \mathrm{mg} / \mathrm{g}$ dry weight), followed by F. arabica (29.68 $\mathrm{mg} / \mathrm{g}$ dry weight), while the lowest value was recorded in F. mollis (12.43 mg/g dry weight). The values of polysaccharides ranged between $88.67 \mathrm{mg} / \mathrm{g}$ dry weight in F. mollis to $167.49 \mathrm{mg} / \mathrm{g}$ dry weight in F. creticus as shown in (Table 1).

Carbohydrates are energy-providing feed components composed of carbon, hydrogen, and oxygen. They should make up about 75 percent of an animal's diet. Carbohydrates are not stored in the body and they must be provided in the animal's diet every day [33]. The highest total carbohydrates content was recorded in F. creticus (678.6 mg/g dry plant) followed by F. arabica $(622.4 \mathrm{mg} / \mathrm{g}$ dry plant) and the lowest was in F. mollis (605.3 mg/g dry plant) (Table 1). On the other hand, the total digestible nutrient (TDN) is only an approximate measure of the food energy available to animals after digestion losses have been deduced [34]. The obtained data showed that, there were no variable differences between the total digestible nutrients' percent of the three studied Fagonia species where the highest total digestible nutrients were in F. mollis $(60.11 \%)$ followed by F. arabica (59.18\%), while the lowest value was in F. creticus $(56.75 \%)$.

The nutritive value of any plant depends upon its content of nutrients producing energy as well as its content of nutrients essential to the body, but the chemical analysis alone is of limited use to evaluate the nutritive value of plants, especially those containing secondary compounds [35]. The aerial parts of $F$. creticus expressed the highest nutritional value among the other F. species. The obtained results showed that F. creticus contains appreciable levels of nutritive content considering that the nutritional value of its leaves $(351.06 \mathrm{kcal} / 100 \mathrm{~g}$ dry weight) was remarkable higher than the other species of F. arabica and F. mollis ( 327.99 and $293.07 \mathrm{kcal} / 100 \mathrm{~g}$ dry weight, respectively).

By comparing the obtained results to those of other plant species in the Egyptian flora, for instance, the nutritive value of Atriplex species, Medicago sativa and Trifolium alexandrinum found to be higher than those of the studied Fagonia species [1, 36-40], while the nutritive values of the studied species of Fagonia genus were higher than the species studied by Maswada [41] and Hendriks et al. [42].

\section{Macro and Micro Elemental Analysis}

Two classes of nutrients are considered essential for plants: macronutrients and micronutrients. Macronutrients (N, P, K, $\mathrm{Mg}$, etc.) are the building blocks of crucial cellular components like proteins and nucleic acids. Micronutrients, including iron, zinc, manganese, and copper, are required in very small amounts as cofactors for enzyme activity [43]. The concentrations of the macro- $\left(\mathrm{K}^{+}, \mathrm{Ca}^{++}, \mathrm{Mg}^{++}, \mathrm{Na}^{+}\right)$and micro-elements $(\mathrm{Fe}$, $\mathrm{Mn}, \mathrm{Zn}$, and $\mathrm{Cu}$ ) estimated in the three studied species are shown in Figures 1 and 2 . It is obvious that the concentration of $\mathrm{Na}$ was relatively the highest among the other estimated macroelements in the studied species followed by K, Ca and $\mathrm{Mg}$, respectively while Fe was the highest microelement followed by $\mathrm{Cu}, \mathrm{Mn}$ and $\mathrm{Zn}$, respectively. The concentrations of sodium, potassium, calcium and magnesium of F. creticus $(13.09,12.09$, 10.69 and $7.19 \mathrm{mg} \mathrm{g}^{-1}$, respectively) were higher than those of the other studied Fagonia species. The concentrations of sodium, potassium, calcium and magnesium in F. arabica were $10.66,2.84,3.47$ and $2.53 \mathrm{mg} \mathrm{g}^{-1}$ while those of $F$. mollis were $7.80,3.75,4.25$ and $2.11 \mathrm{mg} \mathrm{g}^{-1}$, respectively. Dastagir et al. [44]

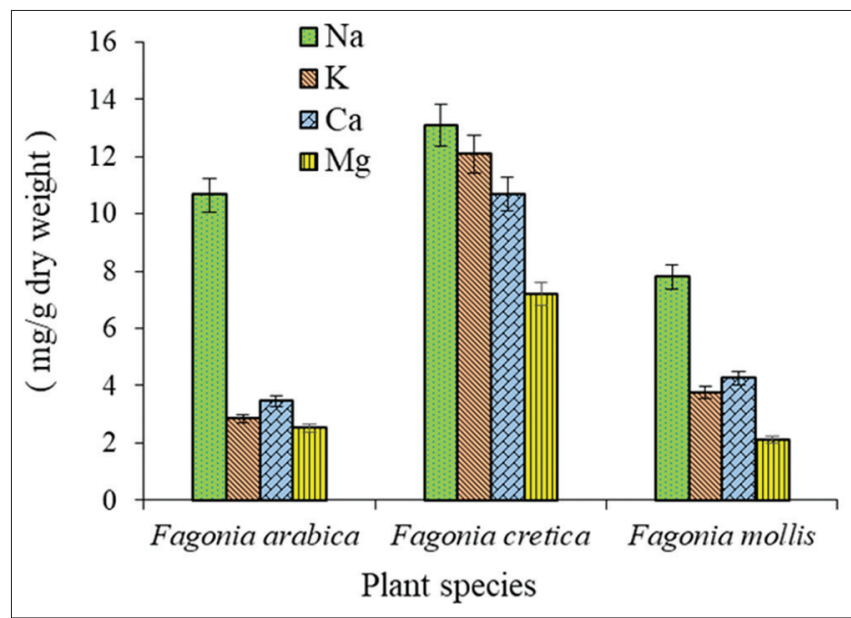

Figure 1: The macro- elements concentrations in the studied Fagonia species

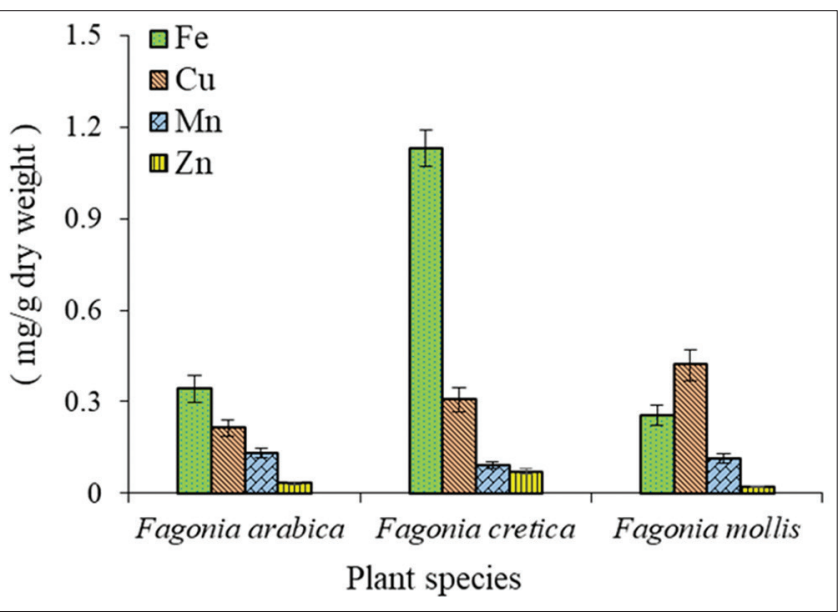

Figure 2: The micro- elements concentrations in the studied Fagonia species 
reported that $\mathrm{Ca}, \mathrm{K}$ and $\mathrm{Mg}$ contents were high in F. cretica which differed from the present findings, also recorded less Na content. While, the present results comparable with other workers as Zafar et al. [45] and Jabeen et al. [46] in the aerial parts of F. indica.

Regarding the micro-elements, F. creticus had the highest iron concentration of $1.13 \mathrm{mg} \mathrm{g}^{-1}$ followed by F. arabica $\left(0.34 \mathrm{mg} \mathrm{g}^{-1}\right)$ while F. mollis showed the lowest concentrations of $0.26 \mathrm{mg} \mathrm{g}^{-1}$. On the contrary, F. mollis had the highest copper concentration of $0.42 \mathrm{mg} \mathrm{g}^{-1}$ followed by Fagonia creticus $\left(0.31 \mathrm{mg} \mathrm{g}^{-1}\right)$ while F. arabica showed very low concentration of $0.21 \mathrm{mg} / \mathrm{g}$ (Figure 2). AI-Rumaih et al. [47] and Dastagir et al. [44] reported high Fe and low $\mathrm{Cu}$ contents in F. cretica which differed from the present investigation, as well as Shad et al. [48] who reported low $\mathrm{Cu}$ contents in F. arabica. These results agree with the findings of Zafar et al. [45] on F. indica.

F. arabica had the highest manganese concentration of $0.13 \mathrm{mg} \mathrm{g}^{-1}$ followed by F. mollis $\left(0.11 \mathrm{mg} \mathrm{g}^{-1}\right)$ while F. creticus showed the lowest concentrations of $0.09 \mathrm{mg} \mathrm{g}^{-1}$. On the contrary, F. creticus had the highest zinc concentration of $0.07 \mathrm{mg} \mathrm{g}^{-1}$ followed by F. arabica $\left(0.04 \mathrm{mg} \mathrm{g}^{-1}\right)$ and F. mollis showed the lowest concentrations of $0.03 \mathrm{mg} / \mathrm{g}$ (Figure 2 ). In the present study Fagonia species had Mn content in the range of $0.09-0.13 \mathrm{mg} \mathrm{g}^{-1}$ and $\mathrm{Zn}$ content in the range of $0.03-0.07 \mathrm{mg} \mathrm{g}^{-1}$ that differed from the findings of Dastagir et al. [44] who reported higher Mn and Zn contents in F. cretica.

Trend of accumulation of macro nutrients in studied Fagonia species showed little variation as given below: $\mathrm{Na}>\mathrm{Ca}>\mathrm{K}>$ $\mathrm{Mg}$ in F. arabica and F. mollis, $\mathrm{Na}>\mathrm{K}>\mathrm{Ca}>\mathrm{Mg}$ in F. cretica while the trend of accumulation of micro nutrients in the same plants showed remarkable variation as given below: $\mathrm{Fe}>\mathrm{Cu}>$ $\mathrm{Mn}>\mathrm{Zn}$ in F. arabica and F. cretica, $\mathrm{Cu}>\mathrm{Fe}>\mathrm{Mn}>\mathrm{Zn}$ in F. mollis. Climatic and atmospheric changes imposed serious effects on plants like the changes occur in the availability of certain nutrients [49] therefore, the mineral contents vary from plant to plant on one hand and from place to place on another hand.

\section{Quantitative Determination of Some Bioactive Secondary Compounds}

The dry and saline habitat of the studied Fagonia species is considered as precursor for them to synthesize many secondary metabolites such as phenolics, flavonoids, alkaloids, saponins and many other compounds that have protective and medicinal properties [50]. Methanol was used for the extraction of the active ingredients of the studied plants. The concentrations of the secondary metabolites in the studied Fagonia species are presented in Figure 3.

The present results showed that the content of phenolics, alkaloids, flavonoids, saponins and tannins were in range of 4.38-9.62, 3.32-4.43, 5.11-7.16, 5.87-8.14 and 6.66-12.44 $\mathrm{mg} \mathrm{g}^{-1}$ dry wt., respectively (Figure 3). Fagonia creticus was found to be the richest in total alkaloids and flavonoids, while F. arabica was found to be the richest among the other studied Fagonia

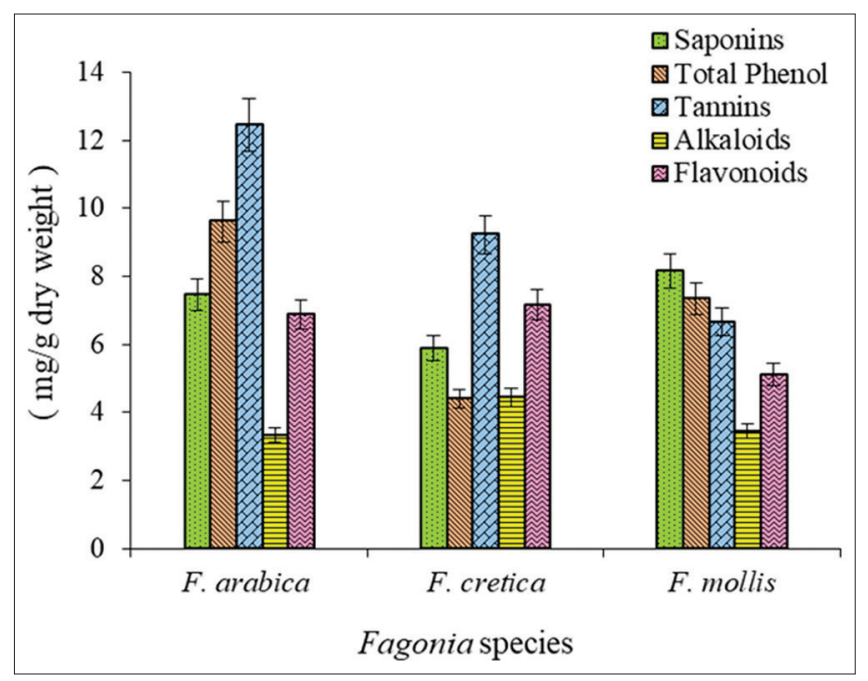

Figure 3: Comparison between the bioactive secondary compounds in the studied Fagonia species

species in total phenol and tannins. These results were in consistency with those reported by Canty et al. [51] and Kara and Sürmen [52] on rangeland and pasture plants.

The content of antinutritional factors in plant depends on secondary metabolites and varies with plant species, phenological period and environmental conditions Poutaraud et al. [53]. According to Sodipo et al. [54] most phytochemicals serve as natural antioxidants, antibiotics, and herbicides which are used as biologically active compounds against microbial invasion and infections. In this research, appreciable quantities of phenolics, alkaloids, flavonoids were obtained in the studied species of genus Fagonia (Figure 3). According to literature, alkaloids have a wide range of pharmacological activities including antimalarial, anticancer [55], antibacterial [56] and antihyperglycemic activities [57]. Flavonoids are known to have antioxidant effects and have been shown to inhibit the initiation, promotion, and progression of tumors [58]. Phenolic compounds are widely distributed in plant tissues, particularly contributing color, flavor, and astringency to fruits, as well as contribute little to the physiological and/or ecological functions of the plant [59].

\section{CONCLUSION}

Weeds are not just plants out of place but it properly regarded useful to humans. Therefore, proximate composition, mineral content and secondary metabolites of the aerial parts of three Fagonia species (Fagonia arabica, F. mollis and F. cretica) were analyzed. Fagonia species are rich by products of secondary metabolites, and therefore, are used in several purposes such as medical uses, agricultural uses. In addition, species of Fagonia contain suitable amounts of protein, fats and elements, and therefore can add amounts of this plant to feed in dry areas

\section{REFERENCES}

1. Zahran, M.A. and El-Amier, Y.A., Non-traditional fodders from the halophytic vegetation of the Deltaic Mediterranean Coastal Desert, 
Egypt. J. Biol. Sci., 2013, 13, 226-233.

2. Jamshidi-Kia, F., Lorigooini, Z. and Amini-Khoei, H., Medicinal plants: Past history and future perspective. J. Herbmed. Pharmaco., 2018, 7.

3. Omoyeni, O.A., Aterigbade, E. Akinyeye, R.O. and Olowu, R.A., Phytochemical screening, nutritional/anti-nutritional and amino acid compositions of Nigeria Melanthera Scandens. Sci. Rev. Chem. Commun., 2012, 2, 20-30.

4. Liu, Y. and Yang L.,, Early metabolism evaluation making traditional Chinese medicine effective and safe therapeutics. J. Zhejiang UnivSc. B., 2006, 7, 99-106.

5. Trache, D., Hussin, M.H., Haafiz, M.M. and Thakur, V.K., Recent progress in cellulose nanocrystals: sources and production. Nanoscale, 2017, 9, 1763-1786.

6. Heneidy, S.Z. and Bidak, L.M., Potential uses of plant species of the coastal Mediterranean region. Pak. J. Biol. Sci., 2004, 7, 1010-1023.

7. Tackholm, V., Students' Flora of Egypt. Cairo University Press, Cairo, Egypt, 1974.

8. Boulos, L., Flora of Egypt, Vol. 2. Al Hadara Publishing, Cairo, Egypt, 2000.

9. Ahsan, H., Muhammed, Z. and Bushra, M., Cytotoxic and antitumor potential of Fagonia critica. Turk. J. Biol., 2007, 31, 19-24.

10. Satpute, R.M., Kashyap, R.S., Deopujari, J.Y., Purohit, H.J., Taori, G.M. and Daginawala, H.F., Protection of PC12 cells from chemical ischemia induced oxidative stress by Fagonia arabica. Food Chem. Toxicol., 2009, 47, 2689-2695.

11. Farheen, R., Mahmood, I. and Parveen, R., Review of medicinal and bioactive role of genus Fagonia fuuast. Fuuast J. Biol., 2017, 1, 33-36.

12. Kamran, S.H., Shoaib, R.M., Ahmad, M., Ishtiaq, S. and Anwar, R., Antidiabetic and renoprotective effect of Fagonia cretica L. methanolic extract and Citrus paradise Macfad. juice in alloxan induced diabetic rabbits. J. Pharm. Pharmacogn. Res., 2017, 5, 365-380.

13. Zaki, A.A., Ali, Z., El-Amier Y.A. and Khan, I.A., A New Neolignan from Panicum turgidum. Natl prod Comm., 2016, 11, p.1934578X1601100729.

14. Zaki, A.A., Ross, S.A., El-Amier, Y.A. and Khan, I.A., New flavans and stilbenes from Cyperus conglomeratus. Phytochem Let., 2018, 26, 159-163.

15. Zaki, A.A., Ali, Z., Wang, Y.H., El-Amier, Y.A., Khan, S.I. and Khan, I.A., Cytotoxic steroidal saponins from Panicum turgidum Forssk. Steroids, 2017, 125, 14-19.

16. Bouyahya, A., Dakka, N., Et-touys, A., Abrini, J. and Bakri, Y., Medicinal plant products targeting quorum sensing for combating bacterial infections. Asian Pac. J. Trop. Med., 2017, 10, 729-743.

17. AOAC., Official methods of analysis, $16^{\text {th }}$ ed. of the Association of Official Analytical Chemists, 15th edition, Arlington, VA, USA. 1995.

18. Pirie, N.W., Protein. In: Modern Methods of Plant Analysis IV, 23, Springer Verlage, Berlin. 1955.

19. Feteris, A.W., A Serum Glucose Method without Protein Precipitation. Am. J. Med. Sci., 1965, 31, 17-21.

20. Handel, E.V., Direct Micro Determinations of Sucrose. Analy. Biochem., 1968, 22, 280-283.

21. Thayumanavan, B. and Sadasivam, S., Physiochemical basis for the preferential uses of certain rice varieties. Plant Food, Human Nutrition, $1984,34,253-259$.

22. Allen, S.E., Grimshaw, H.M., Parkinson, J.A., Quarmby, C. and Roberts, J.D., Chemical Analysis of Ecological Materials. Blackwell Scientific Publ. Osney, Oxford, London, 1974.

23. Sadasivam, S and Manickam, A., Biochemical Methods. 3rd ed. New Age International, Limited, New Delhi, 2008.

24. Van-Buren, J.P. and Robinson, W.B., Formation of complexes between protein and tannic acid. J. Agric. Food Chem., 1969, 17, 772-777.

25. Obadoni, B.O. and Ochuko, P.O., Phytochemical studies and comparative efficacy of the crude extracts of some homeostatic plants in Edo and Delta States of Nigeria. Global J. Pure Appl. Sci., 2001, 8, 203-208.

26. Boham, B.A. and Kocipai-Abyazan, R., Flavonoids and condensed tannins from leaves of Hawaiian Vaccinium vaticulatum and V. calycinium. Pac. Sci., 1974, 48, 458-463.

27. Harborne, J.B., Phytochemical Methods, London. Chapman and Hall, Ltd: 1973, 49-188.

28. Wu, G., Fanzo, J., Miller, D.D., Pingali, P., Post, M., Steiner J.L. and Thalacker-Mercer, A.E., Production and supply of high-quality food protein for human consumption: sustainability, challenges, and innovations. Annals of the New York Academy of Sciences, 2014,
1321:1-19

29. Abuajah, C.I., Ogbonna, A.C. and Osuji, C.M., Functional components and medicinal properties of food: a review. J. Food Sci. Tech., 2015, 52, 2522-2529.

30. Dhingra, D., Michael, M., Rajput, H. and Patil, R.T., Dietary fibre in foods a review. J. Food Sci. Tech., 2012, 49, 255-266.

31. Buchanan, B.B., Gruissem, W. and Jones, R.L., Biochemistry and molecular biology of plants. John Wiley \& Sons, 2015.

32. Wu, G., Dietary protein intake and human health. Food \& function, 2016, 7, 1251-1265.

33. Morrill, J.S., Science Physiology and Nutrition For the Nonscientist. Orange Grove Publishing, 2016.

34. El-Amier, Y.A. and Abdullah, T.J., Evaluation of nutritional value for four kinds of wild plants in Northern sector of Nile Delta, Egypt. Open J. Appl. Sci., 2015, 5, 393-402.

35. Van Soest, P.J., Nutritional ecology of the ruminant. Cornell university press, 2018

36. Khan, A.D., Ejaz, N. and Gilani, A.H., The use of berseem clover (Trifolium alexandrinum L.) pulp residue, after juice extraction, in lamb-finishing diets. Arch. Zootec., 2002, 51, 291-301.

37. El-Shamy, M.M., Studies on some taxa of the genus Acacia in Egypt. PhD Thesis, Fac. Sci., Mansoura Univ., Egypt, 1995.

38. Otal, J., Orengo, J., Quiles, A., Hevia, M.L. and Fuentes, F., Characterization of edible biomass of Atriplex halimus L. and its effect on feed and water intakes, and on blood mineral profile in non-pregnant Manchega-breed sheep. Small Ruminant Research, 2010, 91, 208-214.

39. Stanacev, V., Dukic, D., Kovcin, S., Drinic, M., Puvaca, N. and Stanacev, V., Nutritive value of the genetically divergent genotypes of lucerne (Medicago sativa L.). Afr. J. Agric. Res., 2010, 5, 1284-1287.

40. El-Amier, Y.A. and, Ejgholi, A.A., Fodder Potentialities of Three Halophytes Naturally Growing in Egypt. J. Environ. Sci., 2014, 43, 647-662.

41. Maswada, H.F., Ecological and Physiological Studies on some Geophytes in the Mediterranean Coastal Region of Kafr El-Sheikh Governorate, Egypt. Ph.D. Thesis, Fac. Agric., Tanta Univ., Egypt, 2009.

42. Hendriks, S.J., Donaghy, D.J., Matthew, C., Bretherton, M.R., Sneddon, N.W., Cosgrove, G.P., Christensen, C.L., Kaufononga, S., Howes, J., Osborne, M.A. and Taylor, P.S., Dry matter yield, nutritive value and tiller density of tall fescue and perennial ryegrass swards under grazing. New Zeal. J. Agr. Res., 2016, 78, 149-156.

43. Agegnehu, G., Nelson, P.N. and Bird, M.I., Crop yield, plant nutrient uptake and soil physicochemical properties under organic soil amendments and nitrogen fertilization on Nitisols. Soil Tillage Res., 2016, 160, 1-13.

44. Dastagir, G.H., Hussain F.A. and Rizvi, M.A., Mineral composition of plants of family zygophyllaceae and euphorbiaceae. Pak. J. Bot., 2014, 46, 887-896

45. Zafar, M., Khan, M.A., Ahmad, M., Jan, G., Sultana, S., Ullah K., Marwat, S.K., Ahmad, F., Jabeen, A., Nazir, A., Abbasi1, A.M., Zia-ur-Rehman and Ullah. Z., Elemental analysis of some medicinal plants used in traditional medicine by atomic absorption spectrophotometer (AAS). J. Med. PI. Res., 2010, 4, 1987-1990.

46. Jabeen, S.M., Shah, T., Khan, S. and Hayat, M.Q., Determination of major and trace elements in ten important folk therapeutic plants of Haripur basin, Pakistan. J. Med. Plants Res., 2010, 4, 559-566.

47. Al-Rumaih, M.M., Al-Saad F.A. and Warsy, A.S., Seasonal variation in mineral content of different organs during development of Rumex vesicarius L. Saudi J. Biol. Sci., 2002, 9, 69-76.

48. Shad, A.A., Shah, H., Khattak, F.K., Dar, N.G. and Bakht, J., Proximate and mineral constituents of medicinal herb Fagonia arabica. Asian J. Pl. Sci., 2002, 1, 710-711.

49. Tuomisto, H.L., Scheelbeek, P.F., Chalabi, Z., Green, R., Smith, R.D., Haines A., and Dangour, A.D., Effects of environmental change on agriculture, nutrition and health: a framework with a focus on fruits and vegetables. Wellcome Open Research, 2017, 2, 21.

50. Parida, A.K., Kumari, A., Rangani J. and Patel, M., 19 Halophytes: Potential Resources of Coastal Ecosystems and their Economic, Ecological and Bioprospecting Significance. Halophytes and climate change: adaptive mechanisms and potential uses, 2019, 287-323.

51. Canty, M.J., Fogarty, U., Sheridan, M.K., Ensley, S.M., Schrunk D.E., and More, S.J., Ergot alkaloid intoxication in perennial ryegrass (Lolium perenne): an emerging animal health concern in Ireland? Irish Vet. J., 2014, 67, 1-7. 
El-Zayat, et al.

52. Kara, E., Sürmen, M., The effects of secondary metabolites of rangeland and pasture plants on the animal health in Mediterranean ecological conditions. Am. J. Chinese. Med. Sci., 2019, 16, 63-72.

53. Poutaraud, A., Michelot-Antalik A. and Plantureux, S., Grasslands: a source of secondary metabolites for Livestock health. J. Agric. Food Chem., 2017, 65, 6535-6553.

54. Sodipo, O.A., Akiniyi, J.A. and Ogunbano, U.S., Studies on certain characteristics of extracts of bark of Pausinystalia johimbe and Pausinystalia macroceras (K.Schum.) Pierre ex Beille. Global J. Pure Appl. Sci., 2000, 6, 83-87.

55. Kittakoop, P., Mahidol, C. and Ruchirawat, S., Alkaloids as important scaffolds in therapeutic drugs for the treatments of cancer, tuberculosis, and smoking cessation. Cur. Top. Med. Chem., 2014,
14, 239-252

56. Cushnie, T.P.T., Cushnie, B. and Lamb, A.J., Alkaloids: an overview of their antibacterial, antibiotic-enhancing and antivirulence activities. Int. J. Antimicrob. Agri., 2014, 44, 377-386.

57. Qiu, S., Sun, H. and Zhang etal., A.H., Natural alkaloids: basic aspects, biological roles, and future perspectives. Chin. J. Nat. Med., 2014 12, 401-406.

58. Kim, S.Y., Kim, J.H., Kim, S.K., Oh, M.J. and Jung, M.Y., Antioxidant activities of selected oriental herb extracts. J. Am. Oil Chem. Soc., 1994, 71, 633-640.

59. Kougan, G.B., Tabopda, T., Kuete R. and Verpoorte, V., Simple phenols, phenolic acids, and related esters from the medicinal plants of Africa. In Medicinal Plant Research in Africa, Elsevier, 2013, 225-249. 